\title{
Synthesis, Characterization, Antifungal and Antibacterial Activities of Novel Amide Derivatives of 1,3-Dioxolane
}

\author{
Zahra Begum ${ }^{1}$, Momin Khan ${ }^{2}$, Sher Wali Khan ${ }^{1}$, Muhammad Imran ${ }^{1,4}$, Noor Rehman ${ }^{1}$, Muhammad Naveed Umar ${ }^{3}$, Atif \\ Kamil $^{5}$, Turghun Muhammad ${ }^{4}$ \\ ${ }^{1}$ Department of Chemistry Shaheed BB University Sheringal Dir (U) Khyber Pakhtunkhwa, Pakistan \\ ${ }^{2}$ Department of Microbiology, Institute of Basic Medical Sciences Khyber Medical University, Peshawar, Pakistan \\ ${ }^{3}$ Department of Chemistry, University of Malakand, Khyber Pakhtunkhwa, Pakistan \\ ${ }^{4}$ College of Chemistry and Chemical Engineering, Xinjiang University, Xinjiang P.R China \\ ${ }^{5}$ Department of Biotechnology, Abdul Wali Khan University, Mardan-KP, Pakistan \\ Correspondence: Sher Wali Khan, Department of Chemistry Shaheed BB University Sheringal Dir (U) Khyber \\ Pakhtunkhwa, Pakistan. Email: sherwalikhn@yahoo.co.uk
}

Received: June 26, 2018 Accepted: April 10, 2019 Online Published: April 14, 2019

doi:10.5539/ijc.v11n1p71 URL: https://doi.org/10.5539/ijc.v11n1p71

\begin{abstract}
L-Tartaric acid which is chiral compound and commercially available, was converted into 1,3-dioxolane. In the synthetic sequence, 1,3-dioxolane was first formed via protection and partial hydrolysis of L-tartaric acid. Treatment with altered substituted aromatic amines, 1,3-dioxolane gave the desired amides i.e. ethyl 2,2-dimethyl-5-(phenylcarbamoyl)-1,3-dioxolane-4-carboxylate 3a,

2-(4-(ethoxycarbonyl)-2,2-dimethyl-1,3-dioxolane-5-carboxamido)benzoic acid $\mathbf{3 b}$, ethyl

5-(4-iodophenylcarbamoyl)-2,2-dimethyl-1,3-dioxolane-4-carboxylate 3c, ethyl

5-(2-chlorophenylcarbamoyl)-2,2-dimethyl-1,3-dioxolane-4-carboxylate $3 \boldsymbol{d}$ and ethyl

5-(2,4-dichlorophenylcarbamoyl)-2,2-dimethyl-1,3-dioxolane-4-carboxylate 3e. These chiral derivatives were purified through column chromatographic technique and characterized by different spectroscopic techniques i.e IR, ${ }^{1} \mathrm{H}$ NMR, ${ }^{13} \mathrm{C}$ NMR and EIMS. The antimicrobial activities of these compounds were determined at different concentrations against different strains of bacteria and fungi.
\end{abstract}

Keywords: L-tartaric acid, protection, partial hydrolysis, amides, antimicrobial activity

\section{Introduction}

Tartaric acid is an important chiral compound. Many studies for example selective ion complexation (Leapine, 2005), asymmetric oxidation of prochiral sulfides (Schitter, 1998) and as bio-inspired antifreeze additives (Ilmarinen, 2001) have been carried out on derivatives of tartaric acid. The synthetic development of macrocyclic peptide antibiotics such as biphenomycin B (Yavuz, 2006) and vancomycine type glycopeptides antibiotics (Cupido, 2007) have brought some dramatic changes in the last few years. Synthesis of carbazolophane amides along with their antibacterial and antifungal activities has also been reported (Ghose, 1999). Derivatives of tartaric acid with amide and ester bond, possess interesting biological activities such as anti-inflammatory (Dai, 2011) antifungal (Behr, 2003) antimicrobial (Kucuk, 2011), thrombin inhibition (Dahlgren, 2002) inhibitors of chitin synthase (Xiea, 2012) and $\beta$-secretase inhibitor (Li, 2012).

In the continuation of our research work on organic compounds (Khalid, 2009, sher, 2013, Khalid, 2010) and due to the amide's importance in organic synthesis, we synthesized some novel amides from 1,3-dioxolane of L-tartaric acid. All the compounds were purified via column chromatography and were characterized with the help of spectro analytical techniques including IR, ${ }^{1} \mathrm{H}-\mathrm{NMR},{ }^{13} \mathrm{C}-\mathrm{NMR}$ and EIMS. The amides (3a-e) were tested for their antimicrobial activities at different concentrations against different strains of bacteria and fungi. All the compounds showed good to significant activities against all the three fungal as well as bacterial strains. 


\section{Results and Discussion}

\section{Chemistry}

Tartaric acid is a very important compound and has been used in stereochemical studies due to its optically active nature. Many tartaric acid derivatives have broad applications in numerous chiral compounds preparation and is too used as a parent compound of chiral auxiliaries, chiral ligands, and in the synthesis of bioactive molecule (Gawronski, 1999). In organic synthesis, owing to the grandness of chiral substrates, we designed the synthesis of some novel chiral derivatives with L-tartaric acid backbone. In this research work, L-tartaric acid was selected which is cheapest and enantiomerically pure available compound. L-tartaric acid is a chiral, polar and poly-functional molecule having two asymmetric atoms of carbon $(2 \mathrm{R}, 3 \mathrm{R})$ with absolute configuration possessing $C 2$-axis of symmetry (Figure 1 ).<smiles>O=C(O)[C@@H](O)[C@@H](O)C(=O)O</smiles>

L (+)-Tartaric Acid<smiles>O=C(O)[C@@H](O)[C@@H](O)C(=O)O</smiles>

D ( -)-Tartaric Acid

\section{Figure-1}

Protection and partial hydrolysis of bifunctional L-tartaric acid was carried out to get the monoester 3 as shown in Scheme-1.

\section{Synthesis of diethyl 2,2-dimethyl-1,3-dioxolane-4,5-dicarboxylate (2) and monoester (3)}

The first step for synthesis of L-tartaric acid derivatives was the protection of the diol as 1,3-dioxolane and diacid as diethyl ester. To avert the abdicable side reactions of the -OH groups various protecting groups can be used. In order to prepare 1,3-dioxolane, 2-methoxypropene was selected as a protecting group for the diol group. 1,3-dioxolanes have wide applications, as protecting groups, for 1,2-diols, aldehydes, and ketones in the synthesis of natural products. In basic medium it is stable, very important intermediate, and the end-product of various fragrance, polymer and pharmaceutical industries (Greene, 1991). By using 2,2-dimethoxy propane, Musich et al. reported the 1,3-dioxolane derivatives of 'L and D' tartaric acid (Musich, 1978). Diethyl-L-tartate was first synthesized from L-tartaric acid and ethanol and then 1,3-dioxolane diethyl-L-tartrate (2) synthesis was done (Kozikowski, 1993). Initially the yield was poor but after optimizing the reaction conditions, the yield was improved up to $89 \%$. Via column chromatography the product was purified.

The next step was the partial hydrolysis of compound $\mathbf{2}$ by using lequivalent sodium hydroxide in ethanol. The initial low yield of the desired monoester was improved by increasing the time of reaction from 1-2 hours and by the sodium hydroxide addition drop wise. With $1 \mathrm{M}$ aqueous $\mathrm{KHSO}_{4}$, the resultant salt was acidified. Column chromatography was carried out for the purification of the monoester from some unreacted starting materials and diacid. The monoester $\mathbf{3}$ was obtained as colorless oil, and the yield was $79 \%$. 
<smiles>O=C(O)[C@H](O)[C@@H](O)C(=O)O</smiles>

L-tartaric acid<smiles>CCOC(=O)C(O)C(O)C(=O)OCC</smiles>

1<smiles>CCOC(=O)C1OC(C)(C)OC1C(=O)OCC</smiles>

2<smiles>CCOC(=O)[C@H]1OC(C)(C)O[C@@H]1C(=O)O</smiles>

3

Scheme 1. Synthesis of diethyl 2,2-dimethyl-1,3-dioxolane-4,5-dicarboxylate 2 and monoester 3

The characterization of compound $\mathbf{2}$ and $\mathbf{3}$ was carried out via IR, ${ }^{1} \mathrm{H}$ NMR, ${ }^{13} \mathrm{C}$ NMR and EI-MS. Characteristic absorption frequencies for the compound 2 were shown at 1738 and $2968 \mathrm{~cm}^{-1}$ in the IR absorption spectrum which was attributed to $\mathrm{CO}$ and $\mathrm{C}-\mathrm{H}$ respectively. The spectrum of ${ }^{1} \mathrm{H}$ NMR showed a singlet at $4.76 \mathrm{ppm}$, with 2 protons integration, and was assigned to $\mathrm{CH}, 1,3$-dioxolane's 2 methyl groups appeared as singlet at $1.74 \mathrm{ppm}$ with six protons integration. In ${ }^{13} \mathrm{C}$ NMR spectrum, peak, at $113.7 \mathrm{ppm}$, was assigned to the quaternary carbon atom, while the two-methyl carbon of acetonide appeared at $14.4 \mathrm{ppm}$ respectively. For compound $\mathbf{3}$, characteristic stretching bands at $1708,1730,2972$, and $3511 \mathrm{~cm}^{-1}$ were shown in the IR spectrum. The absorptions were allotted to CO (acid), CO (ester), $\mathrm{C}-\mathrm{H}$ and $\mathrm{OH}$ respectively. ${ }^{1} \mathrm{H}$ NMR spectrum showed a broad singlet at $7.85 \mathrm{ppm}$, with 1 proton integration and was assigned to the $\mathrm{OH}$ group. Two doublets ranging from 4.90-4.80 ppm having coupling constants of $5.4 \mathrm{~Hz}$ appeared for the two methine protons. In the ${ }^{13} \mathrm{C}$ NMR spectrum, peak at $173.8 \mathrm{ppm}$ was attributed to the $\mathrm{CO}$ (acid), which confirmed the hydrolysis.

Chiral amides 3a-e was synthesized from monoester $\mathbf{3}$ and different substituted aromatic amines (scheme 2) by a method first reported by Vaughan and were based on the mixed anhydride (Vaughan, 1951, Vaughan, 1951).<smiles>[R]NC(=O)C1OC(C)(C)OC1C(=O)OCC</smiles>

$\mathrm{R}=$<smiles>Ic1ccccc1</smiles><smiles>O=C(O)c1ccccc1I</smiles>

3b<smiles>Ic1ccc(I)cc1</smiles>

3c<smiles>Clc1ccccc1I</smiles>

3d<smiles>Cc1ccc(Cl)cc1Cl</smiles>

$3 e$

Scheme 2. Synthesis of chiral amides 3a-e 


\begin{tabular}{l|l|l|l|l|l}
\hline S. No. & Code & M.P $\left({ }^{\circ} \mathbf{C}\right)$ & ${ }^{*} \mathbf{R}_{f}$ values & Isolated Yield $(\%)$ & ${ }^{0}(\alpha)$ D \\
\hline 1 & $\mathbf{3 a}$ & Oily & 0.72 & 78 & 20.2 \\
\hline 2 & $\mathbf{3 b}$ & $112-115$ & 0.71 & 77 & 28.4 \\
\hline 3 & $\mathbf{3 c}$ & $135-137$ & 0.69 & 76 & 33.2 \\
\hline 4 & $\mathbf{3 d}$ & $129-131$ & 0.70 & 69 & 27.0 \\
\hline 5 & $\mathbf{3 e}$ & $143-145$ & 0.68 & 73 & 16.5 \\
\hline
\end{tabular}

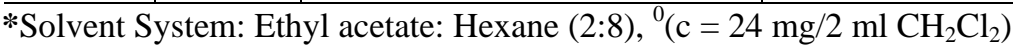

All the compounds 3a-e were refined via column chromatography and characterized with the help of spectro analytical techniques.

\section{Bioassays}

All the synthetic amides (3a-e) were screened for their in vitro antibacterial and antifungal potential against different strains of bacteria (Enterobacter sp, Vibrio Cholera and Klebsiella sp) and fungi (Fausarium solani, Helminthosporium sativum, and Aspergillus niger). The results are listed in Table-1 and Table-2.

\section{Antifungal activity}

All the compounds showed good activity against Fusarium solani, Helminthosporium sativum and Aspergillusn niger at $1000 \mu \mathrm{g} / \mathrm{ml}$ concentration. Compounds 3a, $(66 \%, 80 \%$, 79\%), 3b $(79 \%, 82 \%, 81 \%)$, 3c $(87 \%, 91 \%, 88 \%)$, 3d $(84 \%$, $64 \%, 88 \%), 3 \mathrm{e}(65 \%, 77 \%, 90 \%)$. However, as the concentration decrease to 800 and $600 \mu \mathrm{g} / \mathrm{ml}$ these compounds showed a decline in activity. Compound 3a showed (66\%,80\% and 79\%) inhibition at concentration of $1000 \mu \mathrm{g} / \mathrm{ml}$ against all the three strains of fungi, respectively. As the concentration decreases to 800 and $600 \mu \mathrm{g} / \mathrm{ml}$ there is a decrease in antifungal activity of all the compounds. The results reveal that the same way of inhibition is observed in the activity of compounds of 3a-e. Compound $\mathbf{3 c}$ with para iodo substitution was found to be the most active compound and showed inhibition of fungal strains as $87 \%, 91 \%, 88 \%$, at $1000 \mu \mathrm{g} / \mathrm{ml}$ concentration. Compound 3d and 3e with ortho and para chloro substitution showed $84 \%, 64 \%, 88 \%$ and $65 \%, 77 \%, 90 \%$ activity at $1000 \mu \mathrm{g} / \mathrm{ml}$ concentration Table-1.

Table 1. Antifungal activities of the amides (3a-e) at three different concentrations against three fungal strains

\begin{tabular}{|c|c|c|c|c|c|c|c|c|c|c|}
\hline \multirow{2}{*}{ S. No. } & \multirow{2}{*}{ Compounds } & \multicolumn{3}{|c|}{ Fausarium solani } & \multicolumn{3}{|c|}{ Helminthosporium sativum } & \multicolumn{3}{|c|}{ Aspergillus niger } \\
\hline & & $\begin{array}{l}1000 \mu \mathrm{g} / \\
\mathrm{ml}\end{array}$ & $\begin{array}{l}800 \mu \mathrm{g} \\
/ \mathrm{ml}\end{array}$ & $\begin{array}{l}600 \mu \mathrm{g} / \\
\mathrm{ml}\end{array}$ & $\begin{array}{l}1000 \mu \mathrm{g} \\
/ \mathrm{ml}\end{array}$ & $\begin{array}{l}800 \mu \mathrm{g} \\
/ \mathrm{ml}\end{array}$ & $600 \mu \mathrm{g} / \mathrm{ml}$ & $\begin{array}{l}1000 \mu \\
\mathrm{g} / \mathrm{ml}\end{array}$ & $\begin{array}{l}800 \mu \mathrm{g} / \\
\mathrm{ml}\end{array}$ & $\begin{array}{l}600 \mu \mathrm{g} \\
/ \mathrm{ml}\end{array}$ \\
\hline 1 & $3 \mathbf{a}$ & 66 & 53 & 32 & 80 & 33 & 45 & 79 & 67 & 60 \\
\hline 2 & $\mathbf{3 b}$ & 79 & 44 & 41 & 82 & 42 & 33 & 81 & 42 & 34 \\
\hline 3 & $3 c$ & 87 & 75 & 42 & 91 & 44 & 33 & 88 & 32 & 44 \\
\hline 4 & 3d & 84 & 56 & 51 & 64 & 20 & 36 & 88 & 43 & 42 \\
\hline \multirow[t]{3}{*}{5} & $3 e$ & 65 & 58 & 32 & 77 & 54 & 32 & 90 & 75 & 55 \\
\hline & +Ve control & - & - & - & - & - & - & - & - & - \\
\hline & Terbinafine & 94 & 94 & 94 & 98 & 98 & 98 & 98 & 98 & 98 \\
\hline
\end{tabular}

\section{Antibacterial activity}

All the compounds (3a-e) were also assayed for their antibacterial activities and the results are shown in Table-2. All the compounds in a concentration of $1000 \mu \mathrm{g} / \mathrm{ml}$ exhibited good activity against the tested bacterial strains (Enterobacter $s p$, Vibrio cholera and Klebsiella sp.). The test compounds show a decrease in their antibacterial activities at 800 and $600 \mu \mathrm{g} / \mathrm{ml}$ concentrations. Compounds 3d and 3e with halogen substituents at ortho and para position show significant activity (zone of inhibition 29mm, 28mm for Enterobacter sp, 30mm, $27 \mathrm{~mm}$ for Vibrio cholerae, and $31 \mathrm{~mm}, 19 \mathrm{~mm}$, for Klebsiella sp, respectively) against three bacterial strains at $1000 \mu \mathrm{g} / \mathrm{ml}$ concentration. However, as the concentration decrease to 800 and $600 \mu \mathrm{g} / \mathrm{ml}$ respectively, these compounds showed a drop in their activity. 
Table 2. Antibacterial activity of the protected (3a-e) at three concentrations against bacterial strains. Zone of inhibition are shown in $\mathrm{mm}$.

\begin{tabular}{|c|c|c|c|c|c|c|c|c|c|c|}
\hline \multirow{2}{*}{$\begin{array}{l}\text { S. } \\
\text { No. }\end{array}$} & \multirow{2}{*}{ Code } & \multicolumn{3}{|c|}{ Enterobacter sp. } & \multicolumn{3}{|c|}{ Vibrio cholerae } & \multicolumn{3}{|c|}{ Klebsiella sp. } \\
\hline & & $\begin{array}{l}1000 \mu \mathrm{g} / \\
\mathrm{ml}\end{array}$ & $\begin{array}{l}800 \mu \mathrm{g} / \\
\mathrm{ml}\end{array}$ & $\begin{array}{l}600 \mu \mathrm{g} / \\
\mathrm{ml}\end{array}$ & $\begin{array}{l}1000 \mu \\
\mathrm{g} / \mathrm{ml}\end{array}$ & $\begin{array}{l}800 \mu \mathrm{g} / \\
\mathrm{ml}\end{array}$ & $\begin{array}{l}600 \mu \mathrm{g} / \\
\mathrm{ml}\end{array}$ & $\begin{array}{l}1000 \mathrm{u} \\
\mathrm{g} / \mathrm{ml}\end{array}$ & $\begin{array}{l}800 \mu \mathrm{g} / \\
\mathrm{ml}\end{array}$ & $\begin{array}{l}600 \mu \mathrm{g} / \\
\mathrm{ml}\end{array}$ \\
\hline 1 & $\mathbf{3 a}$ & 22 & 11 & 11 & 22 & 13 & 09 & 20 & 11 & 13 \\
\hline 2 & $\mathbf{3 b}$ & 19 & 13 & 12 & 29 & 15 & 12 & 21 & 15 & 11 \\
\hline 3 & $3 c$ & 28 & 14 & 12 & 27 & 22 & 12 & 19 & 17 & 15 \\
\hline 4 & 3d & 29 & 17 & 13 & 30 & 14 & 11 & 31 & 17 & 16 \\
\hline \multirow[t]{2}{*}{5} & $3 \mathbf{e}$ & 28 & 14 & 15 & 27 & 10 & 11 & 19 & 11 & 12 \\
\hline & Chloramphenicol & 32 & 25 & 34 & 32 & 25 & 34 & 32 & 25 & 34 \\
\hline
\end{tabular}

a Zone of inhibition diameter in mm. (Activity): above $18 \mathrm{~mm}$ (significant activity), 16-18 mm 13-15 mm (low activity), (good activity), 9-12 $\mathrm{mm}$ (non-significant), Below $9 \mathrm{~mm}$ (no activity),

\section{Conclusion}

The amides derivative 3a-e showed more antibacterial and antifungal activity against different bacterial and fungal isolates. The alarming rising resistance in bacteria, to currently available therapeutics is a threat to patients suffering from various diseases. There is need for new therapeutics to be evaluated as antibacterial agents. The synthesized amides may serve as lead compounds for further research in drug designing and medicinal chemistry. These compounds may prove to be promising candidates against different pathogenic strains of fungi.

\section{Experimental}

All chemicals used were of highest available purity and were used as supplied. 2-methoxypropene and L-tartaric acid were purchased from Sigma Aldrich. Through distillation over potassium hydroxide liquid amines were dried and stored in the nitrogen atmosphere over pellets of potassium hydroxide. By using standard procedures, dry solvents like methanol, ether, THF, chloroform, n-hexane and dichloromethane were obtained through distillation. Under anhydrous conditions, reactions were carried out in the atmosphere of nitrogen, rubber septa and three-way stopcocks were used.

All the glassware used were either flame dried instantly before use or were placed in an oven (at $150{ }^{\circ} \mathrm{C}$ ) for $2-3$ hours and were allowed to cool under reduced pressure or in desiccators. Liquid solvents, solutions and reagents were added through rubber septa by means of cannula or syringe. Schlenk type adapters were used for adding solid reagents. Reactions were monitored via TLC on Kieselgel 60 F254 (Merck), methanol/chloroform and ethyl acetate/n-Hexane were used as eluent respectively. Chromatograms were detected under UV light ( $\lambda_{\max } 254$ and $\left.365 \mathrm{~nm}\right)$ and by charring with $10 \% \mathrm{H}_{2} \mathrm{SO}_{4}$ in $\mathrm{EtOH}$, ninhydrine and vanillin respectively.

Column chromatography was carried out by using silica gel (Merck, 230-400 mesh (40-63 $\mu$ m)). Different fractions were concentrated under low pressure by using both a Buchi rotary evaporator (up to $40{ }^{\circ} \mathrm{C}$ bath temperature) at a pressure of either $0.1 \mathrm{~mm} \mathrm{Hg}$ (oil pump) or $15 \mathrm{~mm} \mathrm{Hg}$ (diaphragm pump) as suitable and a high vacuum line (at room temperature). The melting points were determined, by using Gallenkamp digital melting point apparatus, in degree Celsius $\left({ }^{\circ} \mathrm{C}\right)$. IR spectra were recorded on (ATR); Schimadzu Fourier Transform Infrared Spectrophotometer Model 270 and thermo scientific Nicolet $6700 \mathrm{FT}$ IR. $\mathrm{NaCl}$ cell was used for oils while $\mathrm{KBr}$ pellets were used for solid samples. NMR Bruker apparatus was used for ${ }^{1} \mathrm{H}$ NMR and ${ }^{13} \mathrm{C}$ NMR spectra recording at $300 \mathrm{MHz}$ and at $75 \mathrm{MHz}$ respectively. Chemical shifts are given in parts per million (ppm) from residual solvent proton signals or $\mathrm{SiMe}_{4}$ and coupling constants $(J)$ are given in hertz $(\mathrm{Hz})$. different abbreviations are used for multiplicities such as for broad (b), singlet (s), doublet $(\mathrm{d})$, triplet $(\mathrm{t})$, quartet $(\mathrm{q})$, multiplet $(\mathrm{m})$ or combinations. VG: 70 SE mass spectrometer JEOL MS Route instrument having direct probe inlet system was used for EI (Electron impact) mass spectra. For measuring optical rotations of the compounds ATAGO, AP-100 Automatic polarimeter was used.

\section{General procedure for the synthesis of diethyl 2,2-dimethyl-1,3- dioxolane-4,5-dicarboxylate 2}

$10.3 \mathrm{ml}$ or $60 \mathrm{mmol}$ of diethyl-L-tartrate and camphor sulphonic acid (catalytic amount) were taken in a $250 \mathrm{ml}$ round bottom flask and placed in nitrogen atmosphere. $100 \mathrm{ml}$ DMF was added with the help of a syringe and stirred via magnetic stirrer. $7.5 \mathrm{ml}$ or $60 \mathrm{mmol}$ (1.3 eq.) of 2-methoxypropene was added dropwise in 30 min and kept overnight. The reaction was monitored by TLC and after completion; $300 \mathrm{ml}$ of water was added to the reaction mixture and was 
extracted three times with $100 \mathrm{ml}$ ethyl acetate. The organic layer was washed two times with $100 \mathrm{ml}$ of saturated sodium bicarbonate solution, water and three times with $100 \mathrm{ml}$ of brine. The organic layer obtained was dried over anhydrous $\mathrm{MgSO}_{4}$ and was purified via column chromatography (ethyl acetate: n-hexane (2:8) as eluent).

Light yellow oil. Yield: $89 \%$. IR (neat) $\mathrm{cm}^{-1}: 1738(\mathrm{CO}), 2968(\mathrm{CH}) .{ }^{1} \mathrm{H}$ NMR at $300 \mathrm{MHz}\left(\mathrm{CDCl}_{3}\right): \delta$ (ppm): 1.74 (s, $\left.6 \mathrm{H}, \mathrm{C}\left(\mathrm{CH}_{3}\right)_{2}\right), 4.76(\mathrm{~s}, 2 \mathrm{H}, \mathrm{CH}), 4.30-4.23\left(\mathrm{q}, \mathrm{J}=7.2 \mathrm{~Hz}, 4 \mathrm{H}, \mathrm{CH}_{2}\right), 1.33-1.28\left(\mathrm{t}, \mathrm{J}=7.2 \mathrm{~Hz}, 6 \mathrm{H}, \mathrm{CH}_{3}\right), .{ }^{13} \mathrm{C} \mathrm{NMR}$ at 75 $\mathrm{MHz}\left(\mathrm{CDCl}_{3}\right): \delta(\mathrm{ppm}): 14.4 \mathrm{C}\left(\mathrm{CH}_{3}\right)_{2}, 26.3\left(\mathrm{CH}_{3}\right), 61.9 .\left(\mathrm{CH}_{2}\right), 76.6(\mathrm{CH}), 113.7$ (qt C), $169.6(\mathrm{CO})$. EI-MS $\mathrm{m} / z(\%)$ : 172 (76), 188 (51), 230.0 (100), $246.0 \mathrm{M}^{+}(96.1)$.

General procedure for the synthesis of 5-(ethoxycarbonyl)-2,2-dimethyl-1, 3-dioxolane-4-carboxylic acid monoester 3

$6.2 \mathrm{ml}$ or $30 \mathrm{mmol}$ of compound 2 solution in $30 \mathrm{ml}$ ethanol was taken in a $250 \mathrm{ml}$ round bottom flask. $1.2 \mathrm{~g}$ or 30 mmol solution of sodium hydroxide in $30 \mathrm{ml}$ ethanol was added over $30 \mathrm{~min}$. At $25{ }^{\circ} \mathrm{C}$, the reaction mixture was stirred for 2 hour and under low pressure ethanol was evaporated to give a residue. $30 \mathrm{ml}$ water was added and extracted three times with $30 \mathrm{ml}$ dichloromethane (DCM) to recover the diester left unreacted. With $1 \mathrm{M} \mathrm{KHSO}_{4}$, the aqueous layer was acidified and extracted three times with $30 \mathrm{ml}$ DCM. The solvent was evaporated via rotary and, by column chromatography, the crude was purified (MeOH: DCM (2:8) as eluent).

Colorless oil. Yield: $79 \%$. IR (neat) $\mathrm{cm}^{-1}: 1708$ (COOH), 1730 (COOEt), $2972(\mathrm{CH}), 3511(\mathrm{OH}) .{ }^{1} \mathrm{H}$ NMR at $300 \mathrm{MHz}$ $\left(\mathrm{CDCl}_{3}\right): \delta(\mathrm{ppm}): 1.53\left(\mathrm{~s}, 6 \mathrm{H}, \mathrm{C}\left(\mathrm{CH}_{3}\right)_{2}\right), 7.85(\mathrm{bs}, 1 \mathrm{H}, \mathrm{OH}), 4.82-4.80(\mathrm{~d}, J=5.4 \mathrm{~Hz}, 1 \mathrm{H}, \mathrm{CH}), 4.90-4.88(\mathrm{~d}, J=5.4 \mathrm{~Hz}$, $1 \mathrm{H}, \mathrm{CH}), 1.35-1.31\left(\mathrm{t}, \mathrm{J}=7.2 \mathrm{~Hz}, 3 \mathrm{H}, \mathrm{CH}_{3}\right), 4.34-4.27\left(\mathrm{q}, \mathrm{J}=7.2 \mathrm{~Hz} 2 \mathrm{H}, \mathrm{CH}_{2}\right) .{ }^{13} \mathrm{C} \mathrm{NMR}$ at $75 \mathrm{MHz}\left(\mathrm{CDCl}_{3}\right): \delta(\mathrm{ppm})$ : $14.1 \mathrm{C}\left(\mathrm{CH}_{3}\right)_{2}, 26.3\left(\mathrm{CH}_{3}\right), 62.3\left(\mathrm{CH}_{2}\right), 76.5(\mathrm{CH}), 114.2(\mathrm{qt} \mathrm{C}), 169.6\left(\mathrm{COOCH}_{3}\right), 174.4(\mathrm{COOH})$.

\section{General Procedure for the synthesis of chiral amides 3a-e}

$1.09 \mathrm{~g}$ or $5 \mathrm{mmol}$ of compound $3 \mathrm{in} 20 \mathrm{ml}$ THF and $0.91 \mathrm{ml}$ or $5 \mathrm{mmol}$ (1.3 eq.) of triethylamine were placed in a 100 $\mathrm{ml}$ round bottom flask at $0{ }^{\circ} \mathrm{C}$ in the nitrogen atmosphere. $0.58 \mathrm{ml}$ or $5 \mathrm{mmol}$ (1.2 eq.) of ethyl chloroformate was added and was stirred for half an hour; $5 \mathrm{mmol}$ of substituted aniline in $10 \mathrm{ml}$ THF was then added and was allowed to warm to $25^{\circ} \mathrm{C}$ and left overnight. The reaction was monitored by TLC and after completion of the reaction, solvent was removed via rotary and the crude was dissolved in $30 \mathrm{ml}$ of ethyl acetate, washed with $30 \mathrm{ml}$ of $\mathrm{NaHCO}_{3}$ saturated solution, water and brine respectively. The organic layer obtained was dried over anhydrous $\mathrm{MgSO}_{4}$ and purified via column chromatography (ethyl acetate: $\mathrm{n}$-hexane (2:8) as eluent).

\section{Ethyl 2,2-dimethyl-5-(phenylcarbamoyl)-1,3-dioxolane -4-carboxylate 3a}

Yield: $78 \%$. Oily. $(\alpha)_{\mathrm{D}}^{25}=20.2\left(\mathrm{c}=24 \mathrm{mg} / 2 \mathrm{ml} \mathrm{CH}_{2} \mathrm{Cl}_{2}\right)$. $\left(\mathrm{IR} v \mathrm{~cm}^{-1}\right): 3405(\mathrm{NH}), 2928(\mathrm{CH}), 1738(\mathrm{COOEt}), 1689$ $(\mathrm{CONH}), 1535(\mathrm{Ar}) .{ }^{1} \mathrm{H}$ NMR $\left(300 \mathrm{MHz}, \mathrm{CDCl}_{3}\right): \delta(\mathrm{ppm}): 8.29(\mathrm{bs}, 1 \mathrm{H}, \mathrm{NH}), 7.64-7.57(\mathrm{~m}, 5 \mathrm{H}, \mathrm{ArH}), 4.92(\mathrm{~d}, J=5.4$ $\mathrm{Hz}, 1 \mathrm{H}, \mathrm{CH}), 4.82(\mathrm{~d}, J=5.4 \mathrm{~Hz}, 1 \mathrm{H}, \mathrm{CH}), 4.33-4.17\left(\mathrm{q}, \mathrm{J}=7.2 \mathrm{~Hz} 2 \mathrm{H}, \mathrm{CH}_{2}\right), 1.53\left(\mathrm{~s}, 6 \mathrm{H}, \mathrm{C}\left(\mathrm{CH}_{3}\right)_{2}\right), 1.35-1.31(\mathrm{t}, \mathrm{J}=$ $\left.7.2 \mathrm{~Hz}, 3 \mathrm{H}, \mathrm{CH}_{3}\right) .{ }^{13} \mathrm{C}$ NMR $\left(75 \mathrm{MHz}, \mathrm{CDCl}_{3}\right): \delta(\mathrm{ppm}): 170.4(\mathrm{COOEt}), 167.6(\mathrm{CONH}), 114.2(\mathrm{qt} \mathrm{C}), 76.5(\mathrm{CH}), 62.3$ $\left(\mathrm{CH}_{2}\right), 26.3\left(\mathrm{CH}_{3}\right), 14.1 \mathrm{C}\left(\mathrm{CH}_{3}\right)_{2}$. EI-MS m/z (\%): $293.1 \mathrm{M}^{+}$(23.4), 162.8 (46), 83.1 (95.0), 59.1 (100).

\section{2-(4-(ethoxycarbonyl)-2,2-dimethyl-1,3-dioxolane-5-carboxamido) benzoic acid $3 b$}

Yield: $77 \%$. White solid, $\mathrm{m} . \mathrm{p}=112-115^{\circ} \mathrm{C} .(\alpha)_{\mathrm{D}}^{25}=28.4\left(\mathrm{c}=24 \mathrm{mg} / 2 \mathrm{ml} \mathrm{CH}_{2} \mathrm{Cl}_{2}\right)$. $\left(\mathrm{IR} v \mathrm{~cm}^{-1}\right): 3520(\mathrm{OH}), 3403$ $(\mathrm{NH}), 2908(\mathrm{CH}), 1731(\mathrm{COOEt}), 1701(\mathrm{CONH}), 1532(\mathrm{Ar}) .{ }^{1} \mathrm{H}$ NMR $\left(300 \mathrm{MHz}, \mathrm{CDCl}_{3}\right): \delta(\mathrm{ppm}): 11.86(\mathrm{bs}, 1 \mathrm{H}, \mathrm{OH})$, $8.85(\mathrm{bs}, 1 \mathrm{H}, \mathrm{NH}), 7.62-7.51(\mathrm{~m}, 4 \mathrm{H}, \mathrm{ArH}), 4.96(\mathrm{~d}, J=5.4 \mathrm{~Hz}, 1 \mathrm{H}, \mathrm{CH}), 4.80(\mathrm{~d}, J=5.4 \mathrm{~Hz}, 1 \mathrm{H}, \mathrm{CH}), 4.31-4.16(\mathrm{q}, \mathrm{J}$ $\left.=7.2 \mathrm{~Hz} 2 \mathrm{H}, \mathrm{CH}_{2}\right), 1.63\left(\mathrm{~s}, 6 \mathrm{H}, \mathrm{C}\left(\mathrm{CH}_{3}\right)_{2}\right), 1.38-1.31\left(\mathrm{t}, \mathrm{J}=7.2 \mathrm{~Hz}, 3 \mathrm{H}, \mathrm{CH}_{3}\right) \cdot{ }^{13} \mathrm{C} \mathrm{NMR}\left(75 \mathrm{MHz}, \mathrm{CDCl}_{3}\right): \delta(\mathrm{ppm})$ : 172.4 (COOH), 170.4 (COOEt), 167.6 (CONH), 113.2 (qt C), $76.6(\mathrm{CH}), 62.4\left(\mathrm{CH}_{2}\right), 26.1\left(\mathrm{CH}_{3}\right), 14.2 \mathrm{C}\left(\mathrm{CH}_{3}\right)_{2}$. EI-MS $\mathrm{m} / z$ (\%): $337.1 \mathrm{M}^{+}$(12.4), 322 (9.8), 146 (64), 83 (79), 59.1 (100).

\section{Ethyl 5-(4-iodophenylcarbamoyl)-2,2-dimethyl-1,3-dioxolane -4-carboxylate 3c}

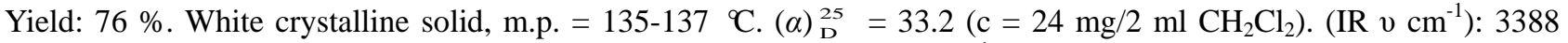
$(\mathrm{NH}), 2925(\mathrm{CH}), 1732$ (COOEt), 1678 (CONH), 1536 (Ar), 1216 (C-I). ${ }^{1} \mathrm{H}$ NMR (300 MHz, CDCl $)_{3}$ : $\delta(\mathrm{ppm}): 8.29$ (bs, $1 \mathrm{H}, \mathrm{NH}), 7.56(\mathrm{~d}, J=8.7 \mathrm{~Hz}, 2 \mathrm{H}, \mathrm{Ar}-\mathrm{H}), 7.34(\mathrm{~d}, J=8.6 \mathrm{~Hz}, 2 \mathrm{H}, \mathrm{Ar}-\mathrm{H}), 4.91(\mathrm{~d}, J=5.4 \mathrm{~Hz}, 1 \mathrm{H}, \mathrm{CH}), 4.80(\mathrm{~d}, J=$ $5.4 \mathrm{~Hz}, 1 \mathrm{H}, \mathrm{CH}), 4.31-4.17\left(\mathrm{q}, \mathrm{J}=7.2 \mathrm{~Hz} 2 \mathrm{H}, \mathrm{CH}_{2}\right), 1.52\left(\mathrm{~s}, 6 \mathrm{H}, \mathrm{C}\left(\mathrm{CH}_{3}\right)_{2}\right), 1.33-1.31\left(\mathrm{t}, \mathrm{J}=7.2 \mathrm{~Hz}, 3 \mathrm{H}, \mathrm{CH}_{3}\right) .{ }^{13} \mathrm{C}$ NMR (75 MHz, $\left.\mathrm{CDCl}_{3}\right): \delta(\mathrm{ppm}): 170.4$ (COOEt), $167.6(\mathrm{CONH}), 114.1$ (qt C), $76.6(\mathrm{CH}), 62.5\left(\mathrm{CH}_{2}\right), 26.5\left(\mathrm{CH}_{3}\right)$, 14.2 $\mathrm{C}\left(\mathrm{CH}_{3}\right)_{2}$. EI-MS $m / z$ (\%): $419.1 \mathrm{M}^{+}$(18.4), 345 (8.5), 219 (4.6), 85 (45.8), 59.1 (100).

\section{Ethyl 5-(2-chlorophenylcarbamoyl)-2,2-dimethyl-1,3-dioxolane -4-carboxylate 3d}

Yield: $69 \%$. White crystalline solid, m.p. $=129-131{ }^{\circ} \mathrm{C} .(\alpha){ }_{\mathrm{D}}^{25}=27.0\left(\mathrm{c}=24 \mathrm{mg} / 2 \mathrm{ml} \mathrm{CH}_{2} \mathrm{Cl}_{2}\right) .\left(\mathrm{IR} \mathrm{v} \mathrm{cm}{ }^{-1}\right): 3399$ $(\mathrm{NH}), 2922(\mathrm{CH}), 1737(\mathrm{COOEt}), 1676(\mathrm{CONH}), 1539(\mathrm{Ar}), 1123(\mathrm{C}-\mathrm{Cl}) .{ }^{1} \mathrm{H}$ NMR $\left(300 \mathrm{MHz}, \mathrm{CDCl}_{3}\right): \delta(\mathrm{ppm}): 8.29$ (bs, $1 \mathrm{H}, \mathrm{NH}), 7.64-7.57(\mathrm{~m}, 4 \mathrm{H}, \mathrm{ArH}), 4.92(\mathrm{~d}, J=5.4 \mathrm{~Hz}, 1 \mathrm{H}, \mathrm{CH}), 4.82(\mathrm{~d}, J=5.4 \mathrm{~Hz}, 1 \mathrm{H}, \mathrm{CH}), 4.33-4.17(\mathrm{q}, \mathrm{J}=7.2$ $\left.\mathrm{Hz} 2 \mathrm{H}, \mathrm{CH}_{2}\right), 1.53\left(\mathrm{~s}, 6 \mathrm{H}, \mathrm{C}\left(\mathrm{CH}_{3}\right)_{2}\right), 1.35-1.31\left(\mathrm{t}, \mathrm{J}=7.2 \mathrm{~Hz}, 3 \mathrm{H}, \mathrm{CH}_{3}\right) .{ }^{13} \mathrm{C} \mathrm{NMR}\left(75 \mathrm{MHz}, \mathrm{CDCl}_{3}\right): \delta(\mathrm{ppm}): 170.4$ 
(COOEt), $167.6(\mathrm{CONH}), 114.2$ (qt C), $76.5(\mathrm{CH}), 62.3\left(\mathrm{CH}_{2}\right), 26.3\left(\mathrm{CH}_{3}\right), 14.1 \mathrm{C}\left(\mathrm{CH}_{3}\right)_{2}$. EI-MS m/z $(\%): 329(6.5)$, $327.1 \mathrm{M}^{+}$(19.4), 312 (15.0), 173 (42.4), 127 (81.1), 83.1 (98.0), 59.1 (100).

\section{Ethyl 5-(2,4-dichlorophenylcarbamoyl)-2,2-dimethyl-1, 3-dioxolane-4-carboxylate 3e}

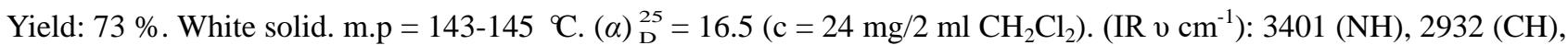
1732 (COOEt), 1677 (CONH), 1533 (Ar), 1103 (C-Cl). ${ }^{1} \mathrm{H}$ NMR (300 MHz, CDCl $\left.)_{3}\right): \delta(p p m): 8.29$ (bs, $\left.1 \mathrm{H}, \mathrm{NH}\right)$, 7.64-7.57 (m, 4H, ArH), $4.92(\mathrm{~d}, J=5.4 \mathrm{~Hz}, 1 \mathrm{H}, \mathrm{CH}), 4.82(\mathrm{~d}, J=5.4 \mathrm{~Hz}, 1 \mathrm{H}, \mathrm{CH}), 4.33-4.17\left(\mathrm{q}, \mathrm{J}=7.2 \mathrm{~Hz} 2 \mathrm{H}, \mathrm{CH}_{2}\right)$, $1.53\left(\mathrm{~s}, 6 \mathrm{H}, \mathrm{C}\left(\mathrm{CH}_{3}\right)_{2}\right), 1.35-1.31\left(\mathrm{t}, \mathrm{J}=7.2 \mathrm{~Hz}, 3 \mathrm{H}, \mathrm{CH}_{3}\right) .{ }^{13} \mathrm{C} \mathrm{NMR}\left(75 \mathrm{MHz}, \mathrm{CDCl}_{3}\right): \delta(\mathrm{ppm}): 170.4(\mathrm{COOEt}), 167.6$ $(\mathrm{CONH}), 114.2$ (qt C), $76.5(\mathrm{CH}), 62.3\left(\mathrm{CH}_{2}\right), 26.3\left(\mathrm{CH}_{3}\right), 14.1 \mathrm{C}\left(\mathrm{CH}_{3}\right)_{2}$. EI-MS m/z (\%): $363.0(15.0), 361.0 \mathrm{M}^{+}(23.4)$, 288.1 (9.0), 173 (47.3), 161 (62.1), 83.1 (100.0), 59.1 (79.0).

\section{Material and Methods}

\section{Assay for Antifungal activity}

In the present experiment three concentrations $(1000,800$ and $600 \mu \mathrm{g} / \mathrm{ml})$ of synthetic compounds were used to study the inhibition potential against three fungal and three bacterial strains. for the antifungal activity determination of the compounds the agar tube dilution method was used (Washington, 1980). DMSO was used as a control solvent; terbinafine was used as the standard antifungal agent. The fungal strains were used in this study include Fusarium solani, Helminthosporium sativum and Aspergillus niger. Each fungal strain was maintained on Sabouraud dextrose agar (SDA) medium at $4{ }^{\circ} \mathrm{C}$.

\section{Antibacterial Bioassay}

Three bacterial strains were used in the study i.e Enterobacter sp, Vibrio cholerae and Klebsiella sp. Agar well diffusion method was used to check the antibacterial activities of the compounds.First nutrient broth medium was prepared by dissolving $0.4 \mathrm{~g}$ of nutrient broth in $50 \mathrm{~mL}$ of distilled water, $\mathrm{pH}$ was adjusted at 7.0 and was autoclaved. Then nutrient agar medium was prepared by dissolving $2.3 \mathrm{~g}$ nutrient agar medium in $100 \mathrm{~mL}$ of distilled water; $\mathrm{pH}$ was adjusted at 7.0 and was autoclaved at $121^{\circ} \mathrm{C}$. After autoclaving the medium was poured in petri plates. A $0.5 \mathrm{McFarland}$ standard was prepared by mixing $0.05 \mathrm{~mL}$ of $1.175 \%$ Barium Chloride dihydrate $(\mathrm{BaCl} 2 \cdot 2 \mathrm{H} 2 \mathrm{O})$, with $9.95 \mathrm{~mL}$ of $1 \% \mathrm{Sulfuric}$ Acid $\left(\mathrm{H}_{2} \mathrm{SO}_{4}\right)$. A $0.5 \mathrm{McFarland}$ standard corresponds to approximately 1.5 x 108 cells per mL. Bacterial were cultured one day before the assay in nutrient broth medium suspension. The bacterial inoculum was adjusted according to 0.5 McFarland standard and added to nutrients agar plates. The test compounds in different concentrations were added to the wells of the petri plates and incubated at $37^{\circ} \mathrm{C}$ for $24 \mathrm{hrs}$. The zones of inhibition of the test compounds was measured after $24 \mathrm{hrs}$. The results were recorded and interpreted accordingly (Koneman, 1994).

\section{Conflict of Interest}

The author(s) confirm that this article content has no conflict of interest.

\section{Acknowledgments}

This work was financially supported by Higher Education Commission (HEC), Pakistan and National Research Program (NRPU) for Universities.

\section{References}

Behr, J. B., Gourlain, T., Helimi, A., \& Guillerm, G. (2003). Bioorg. Med. Chem. Lett. 13, 1713-1716.

Bode, J. W. (2006). Current Opinion in Drug Discovery \& Development, 9, 765.

Coppola, G. M., \& Schuster, H. F. (1997). R-Hydroxy Acids in Enantioselective Synthesis; Wiley-VCH: Weinheim

Cupido, T., Puche, J., Spengler, J., \& Albericio, F. (2007). Current Opinion in Drug Discovery and Development, 10, 768

Dahlgren, A., Branalt, J., Kvarnstrom, I., Nilsson, I., Musilc, D., \& Samuelssond, B. (2002). Bioorg. Med. Chem. 10, 1567-1580,

Dai, C., Li, D., Popovici-Muller, J., Zhao, L., Girijavallabhan, V., Rosner, K., ... Siddiqui, M. A. (2011). Bioorg. Med. Chem. Lett., 21, 3172-3176. https://doi.org/10.1016/j.bmcl.2011.01.002

Gawronski, J., \& Gawronska, K. (1999). Tartaric and Malic Acids in Synthesis-A Source Book of Building Blocks, Ligands, Auxiliaries, and Resolving Agents; J. Wiley and Sons: New York,

Ghose, A. K., Viswanadhan, V. N., \& Wendoloski, J. (1999). Journal of Combinatorial Chemistry, 1 , 55. https://doi.org/10.1021/cc9800071

Ghosh, A. K., Koltun, E. S., \& Bilcer, G. (2001). Tartaric acid and tartrates in the synthesis of bioactive molecules. Synthesis, 1281. https://doi.org/10.1055/s-2001-15217 
Greene, T. W., \& Wuts, P. G. M. (1991). Protective Groups in Organic Synthesis, 2nd ed.; John Wiley \& Sons: New York, NY, USA, 129-133.

Hussain, Z., Khan, K. M., Perveen, S., Nawaz, Y., \& Bukhari, I. H. (2009). Journal of Chemical Society of Pakistan, 33, 694

Ilmarinen, K., Kriis, K., Paju, A., Pehk, T., \& Lopp, M. (2001). Proceedings of the Estonian Academy of Sciences, Geology, 50, 147.

Khan, K. M., Ahmad, A., Ambreen, N., Aymn, A., Perveen, S., Khan, S. A., \& Choudhary, M. I. (2009). Letter in Drug Design and Discovery, 6, 363. https://doi.org/10.2174/1570180810906050363

Khan, K. M., Ali, M., Farooqui, T. A., Khan, M., Taha, M., \& Perveen, S. (2011). Journal of Chemical Society of Pakistan, 31,823 .

Khan, K. M., Ambreen, N., Mughal, U. R., Jalil, S., Perveen, S., \& Choudhary, M. I. (2010). European Journal of Medicinal Chemistry 45, 4058. https://doi.org/10.1016/j.ejmech.2010.05.065

Khan, S. W., Zaidi, J. H., Yousuf, S., Khan, K. M., Ambreen, N., Khan, M., Perveen, S., \& Miana, G. A. (2013). J. Chem. Soc. Pak, Vol. 35, No.3, 875-885.

Koneman, E. (1996). Diagnostic microbiology. Vogel's Textbook of Practical Organic Chemistry, $4^{\text {th }}$ Ed., ELBS Edition, William Clowes Limited, Beccles and London, p. 1131.

Kozikowski, A. P., Ognyanov, V. I., Fauq, A. H., Nahorski, S. R., \& Wilcox, R. A. (1993). J. Am. Chem. Soc. 115, 4429-4434. https://doi.org/10.1021/ja00064a002

Kucuk, H. B., Yusufoglu, A., Mataraci, E., \& Dosler, S. (2011). Molecules, 16, 6806-6815.

Leapine, R., \& Zhu, J. (2005). Organic. Letter, 14, 2981. https://doi.org/10.1021/o1050949w

Li, S., Liao, G., Xiao, J., Nie, A., Wang, L., Zhong, W., \& Zheng, Z. (2012). US Patent, 8, 268, 884 B2,

Musich, J. A., \& Rapoport, H. (1978). J. Am. Chem. Soc. 100, 4865-4872. https://doi.org/10.1021/ja00483a037

Schitter, M. E. R., Jocham, D., Saf, R., Mirtl, C., Stelzer, F., \& Hummel, K. (1998). Journal of Molecular Catalysis A Chemistry, 133, 75.

Vaughan, J. R. (1951). J. Am. Chem. Soc. 3547. https://doi.org/10.1021/ja01151a554

Vaughan, J. R., \& Osato, R. L. (1951). J. Am. Chem. Soc. 5553-5555. https://doi.org/10.1021/ja01156a011

Washington, J. A. H., \& Sutter, V. L. (1980). 453-458. In E. H. Lennette.; Balows, A.; Hausler, W. J.; Truant, J. P. (ed.), Manual of clinical microbiology, 3rd ed. American Society for Microbiology, Washington, D. C.

Xiea, J., Thellend, A., Becker, H., \& Vidal-Crosb, A. (2001). Carbohyd. Res., 334 177-182. https://doi.org/10.1016/S0008-6215(01)00191-4

Yavuz, E., Yagci, M. A., \& Hans, G. B. (2006). Macromolecular Rapid Communications, 27, 1660. https://doi.org/10.1002/marc.200600451

\section{Copyrights}

Copyright for this article is retained by the author(s), with first publication rights granted to the journal.

This is an open-access article distributed under the terms and conditions of the Creative Commons Attribution license (http://creativecommons.org/licenses/by/4.0/). 